\title{
MINAT BELAJAR SISWA DALAM MENINGKATKAN KECERDASAN INTELEKTUAL SISWA SD NEGERI WILAYAH KABUPATEN PANDEGLANG
}

\author{
E. Nita Prianti ${ }^{1}$, Khristina Sri Prihatin ${ }^{2}$ \\ Universitas Banten Jaya \\ Serang, Indonesia \\ Nitaprianti18@gmail.com ${ }^{1}$, Khristina.sprihatin@gmail.com²
}

\begin{abstract}
Based on the fact that there is no end to the problems of education that occur in our country even though the government has worked hard to change it. The irrelevance between expectations, the process and the results achieved in education. Thus there are certainly other factors, one of which is the willingness or interest of students towards learning. The purpose of this study is 1) To find out how much the students' willingness to learn in improving the intellectual intelligence of students of SD Negeri Pandeglang district. 2) To find out the factors and efforts to improve the intellectual intelligence of students of SD Negeri Pandeglang district. The method used in this research is descriptive method with a qualitative approach. While the data source was obtained through informants as research subjects using data collection techniques in library research and field research (research locations) by observing, documenting, interviewing guidelines for several informants namely students, teachers (SD) in the State of Pandeglang Regency. Then the data is analyzed correctly. The data obtained from the results of the study is that students 'interest in learning to improve students' intellectual intelligence in the area of Pandeglang Regency cannot be categorized well. This can be proven from the findings of researchers that students of the SD Negeri Pandeglang Regency will their interest in learning only reach 50\%. From 4 schools based on the results of research data, with a low willingness to learn so that $32.18 \%$ of students cannot read and write.
\end{abstract}

Keywords: Student Learning Interest, Intellectual Intelligence

\section{PENDAHULUAN}

Sesuai yang dijelaskan dalam UndangUndang No.20 Tahun 2003 bahwa pendidikan ditujukan untuk mewujudkan proses pembelajaran agar peserta didik secara aktif mengembangkan potensi diri, kepribadian, kecerdasan, akhlak, keterampilan, yang diperlukan oleh bangsa dan Negara. Dalam bunyi Undang-Undang tersebut sudah cukup jelas bahwa dalam pendidikan tidak dapat diartikan hanya sebagai transfer ilmu saja, melainkan dalam proses pendidikan dimaknai sebagai proses pematangan kualitas hidup.

Sehingga dalam proses pendidikan setiap manusia mampu memahami hakikat hidupnya secara benar dan menciptakan manusia yang kompetensi (Prianti:2019). Dalam pendidikan itu untuk mendapatkan hasil belajar yang baik tentu tidak cukup menyediakan guru yang baik pula yang mampu mengkomunikasikan dan mentransfer ilmu semata kepada siswa, akan tetapi diperlukan juga siswa yang berkemauan dan siap untuk menerima ilmu yang diajarkan oleh guru. Hal tersebut sebagai penunjang keberhasilan belajar 
siswa sebagai individu yang berkompetensi. Hasil belajar siswa tidak hanya tergantung pada kualitas dan kuantitas belajar siswa dengan kata lain siswa juga ikut berperan dan bertanggung jawab atas hasil belajar yang dicapai. Prestasi belajar ini mempunyai hubungan yang berbanding lurus dengan tingkat pemahaman. Ini berarti bila tingkat pemahaman tinggi maka hasil belajar juga cenderung tinggi, bila tingkat pemahaman rendah maka hasil belajar juga cenderung rendah.

Seseorang dianggap cerdas secara intelektual apabila dapat melakukan perbuatan intelegen sebagaimana sesuai ciri-ciri berikut; (a) memiliki kecakapan berfikir, mengamati, dan memahami c) mampu menyelesaikan masalah (b) mampu mencapai tujuan secara cepat (c) mampu memberi keterangan yang diterima oleh masyarakat, (Baharuddin : 2010).

Sebagai bukti menyatakan berdasarkan hasil penelitian Badan Litbang Depdikbud RI menyatakan bahwa tingkat kemampuan membaca para siswa kelas VI sekolah dasar di Indonesia masih rendah. Simpulan ini ditarik dari data penelitian bahwa 76,95 $\%$ siswa kelas VI SD tidak dapat menggunakan kamus. Diantara yang mampu menggunakan kamus ternyata hanya 5\% yang mampu dapat mencari kata dalam kamus bahasa Indonesia secara sistematis dan benar. Kegagalan tersebut disebabkan beberapa factor salah satunya adalah kurangnya kompetensi guru artinya tingkat keprofesionalan guru yang tidak menunjang dan tidak tepat sasaran dalam pembelajaran.

Selain itu, kurangnya faktor intern siswa itu sendiri yang dapat menunjang kecerdasan bagi siswa. Faktor intern tersebut salah satunya adalah minat dan kemauan belajar siswa itu sendiri yang masih dianggap sangat rendah. Akan tetapi jika sebaliknya apabila bentuk motivasi belajar tersebut seluruhnya diciptakan dan diterapkan maka tujuan dan keberhasilan pendidikan dapat tercapai. Senada dengan permasalahan pendidikan yang terjadi di wilayah pandeglang, tingkat ketercapaian dalam pendidikan dianggap rendah.

Hal tersebut dapat terlihat dari semakin meningkatnya jumlah pengangguran, masih banyaknya anak yang putus sekolah, kurangnya kreatifitas anak dalam berinovasi selama pembelajaran, pembentukan karakter anak yang tidak menunjang, tidak adanya kedisiplinan. Permasalahan tersebut bukan karena kurikulum yang salah, melainkan kemungkinan dari faktor guru itu sendiri yang dianggap keliru dalam mengimplementasikan bentuk profesionalitasnya sebagai guru. Sehingga luaran yang dicapai tidak menghasilkan peserta didik yang kompeten, karena siswa lebih cenderung tidak ada kemauan atau 
minat belajar, dikarenakan peran guru dalam berupaya tidak merangsang anak untuk berkemauan dalam belajar.

Permasalah pendidikan di wilayah Pandeglang tersebut dibenarkan dan disampaikan pula oleh Badan Pusat Statistik (BPS) Kabupaten Pandeglang pada hari kamis (10/10/2019). Dari data BPS (Badan Pusat Statistik), bahwa tingkat pendidikan masyarakat Pandeglang terbilang rendah. Berdasarkan data persentase penduduk berumur 7-24 tahun pada 2018 masih banyak yang putus sekolah. Di kelompok umur itu tercatat $32,77 \%$ sudah putus sekolah. Sementara di kelompok umur itu ada $0,48 \%$ yang belum pernah bersekolah. Ada 40,41\% yang masih duduk di SD, kemudian ada $15,6 \%$ masih duduk di SMP dan 10,74\% duduk di SMA. Melalui permasalahan pendidikan di wilayah Pandeglang tersebut. Maka Tim Peneliti merasa terdorong untuk melakukan penelitian dengan tujuan untuk mengetahui seberapa besar kemauan siswa selama pembelajaran dan upaya apa saja yang sudah dilakukan dalam meningkatkan kemauan belajar siswa dalam meningkatkan kecerdasan intelektual siswa sesuai dengan pembangunan nasional yang diharapkan. Melihat permasalahan tersebut maka kami sebagai peneliti mengangkat permasalahan itu ke dalam judul penelitian yaitu "Minat Belajar Siswa Dalam Meningkatkan
Kecerdasan Intelektual Siswa Sekolah Dasar (SD) Negeri Wilayah Kabupaten Pandeglang Banten".

\section{METODE PENELITIAN}

Penelitian ini dilaksanakan mulai pada bulan Juli 2019 bertempat di Sekolah Dasar (SD) Negeri Wilayah Kabupaten Pandeglang. Diantaranya adalah Sekolah Dasar (SD) Negeri 1 Cilentung-Pulosari Pandeglang, Sekolah Dasar (SD) Negeri 1 Sukasari-Pulosari Pandeglang, Sekolah Dasar (SD) Negeri 2 Jiput-Jiput Pandeglang, Sekolah Dasar (SD) Negeri 4 Jiput-Jiput Pandeglang. Informan yang diteliti dalam penelitian ini adalah siswa/siswi dan guru sekolah dasar (SD) Negeri sesuai tercantum di atas. Pendekatan yang digunakan dalam penelitian ini adalah pendekatan kualitatif yaitu prosedur penelitian yang menggambarkan suatu keadaan dan gejala yang ada pada objek yang akan diteliti. Sesuai yang dijelaskan oleh (Sugiyono:2016) bahwa penelitian kualitatif adalah penelitian yang menggambarkan, mendeskripsikan dengan apa yang dilihat, didengar, dirasakan, dan ditanyakan. Adapun teknik pengumpulan data yang dilakukan Tim peneliti pada penelitian ini adalah :

a) Riset kepustakaan (Library Research) yaitu dengan pemgumpulan data dengan membaca literatur-literatur 
kepustakaan yang berhubungan dengan masalah yang diteliti

b) Riset lapangan (Filed Research) yaitu dilakukan dengan cara mengadakan penelitian di lapangan dengan menggunakan teknik sebagai berikut:

1). Observasi terstruktur

Dimana tim peneliti mengumpulkan data dengan melakukan penelitian langsung ke lokasi penelitian yang telah dirancang secara sistematis tentang apa yang akan diamati. Seperti halnya yang di jelaskan oleh Sugiyono (2016) bahwa observasi terstruktur dilakukan apabila peneliti sudah ada kepastian tentang variable yang akan diamati dengan menggunakan instrument penelitian yang telah teruji.

2). Wawancara

Tim peneliti melakukan penyebaran daftar pertanyaan yang sama kepada informan secara lisan dan tulisan untuk pengumpulan data kepada guru dan siswa/siswi sekolah dasar (SD) Negeri di wilayah Kabupaten Pandeglang. Dalam hal ini peneliti mempertanyakan pertanyaan-pertanyaan yang sudah disediakan dan terstruktur yang kemudian diperdalam untuk memperoleh keterangan lebih lanjut sehingga jawaban yang diperoleh meliputi semua variabel dengan keterangan yang lengkap dan mendalam (Arikunto:2013).

3) Dokumentasi

Tim Peneliti melakukan dokumentasi untuk mencari data mengenai hal-hal yang berkaitan dengan variabel yang berupa catatan, transkrip, buku, surat kabar, majalah, hasil rapat dan agenda lainnya yang dapat mendukung tim dalam penelitian.

\section{HASIL DAN PEMBAHASAN}

Berdasarkan data hasil temuan dan analisis data dalam penelitian ini, maka peneliti akan memaparkan hasil dan membahas lebih dalam mengenai bagaimana Profesionalisme Guru, fasilitas belajar, dan Minat Belajar Siswa dalam Meningkatkan Kecerdasan Intelektual Siswa SD Negeri Wilayah Kabupaten Pandeglang. Dalam penelitian ini tentu kami peneliti ingin menggali permasalahan sesuai yang telah dirumuskan. Sebagaimana yang telah ditegaskan dalam teknik analisis penelitian kualitatif bahwa hasil data-data yang diperoleh peneliti melalui observasi, wawancara dan dokumentasi dengan 
subjek penelitian akan dipaparkan secara mendalam, yang selanjutnya data-data tersebut dihubungkan dengan teori untuk menghasilkan ketajaman isi data penelitian.

\section{Minat Belajar Siswa dalam Meningkatkan Kecerdasan Intelektual Siswa SD Negeri Wilayah Kabupaten Pandeglang.}

Setiap siswa dipastikan memiliki minat dalam pembelajaran. Dengan demikian sebagai guru tentu harus ada kemampuan dalam mengembangkan minat siswa tersebut. Jika minat belajar siswa dapat dikembangkan dengan baik maka kecerdasan intelektual dapat diperolehnya. Dengan adanya minat dan kemauan belajar maka kegiatan belajar akan menjadi sesuatu yang menyenangkan bagi siswa,sehingga pendidik dapat dengan mudah untuk melakukan kegiatan belajar mengajar, dan tujuan pembelajaran dapat terpenuhi secara optimal.

Ada hal-hal yang mendominasi mengenai kecerdasan intelektual siswa selain dari profesionlitas ataupun sarana yaitu faktor internal siswa itu sendiri. Yang mana faktor internal itu yang paling mendominasi adalah faktor minat atau kemauan. Minat merupakan faktor psikologis yang mempengaruhi kemauan belajar. Bagaimana cara guru dalam menciptakan minat dan kemauan siswa dalam belajar hal ini pula merupakan salah satu bentuk profesionalitas guru. Dengan demikian, guru harus memotivasi sepenuhnya bagaimana caranya agar siswa mau belajar. Minat dipastikan dapat mempengaruhi semangat belajar siswa tanpa adanya unsur subjektif yang mempengaruhinya.

Berdasarkan data hasil temuan yang peneliti peroleh mengenai minat belajar siswa dalam meningkatkan kecerdasan intelektual siswa SD Negeri Wilayah Kabupaten Pandeglang. Dilihat dari sikap, antusias siswa dapat dikategorikan masih kurang, artinya siswa secara sadar mempunyai kemauan belajar tapi kurang untuk dilakukan. Hasil tersebut dapat dibuktikan melalui hasil perolehan data yang ditemukan peneliti yaitu mencapai 50 \% kemauan belajar siswa, artinya dengan angka tersebut masuk ke dalam kategori masih kurang. Dengan demikian tentu perlu adanya perbaikan untuk merangsang minat belajar siswa.

Dipandang dari sisi pemahaman sesuai hasil data selama peneliti melakukan penelitian menunjukan sebagian kecil mempunyai pemahaman belajar dan sebagian besar siswa kurang dalam pemahaman belajar. Sesuai yang peneliti temukan dilapangan yang mempunyai pemahaman belajar identik dengan siswa yang mempunyai kecerdasan dan bakat 
atau faktor bawaan. Sedangkan siswa yang kurang kecerdasannya identik tidak merespon dan tidak bereaksi dalam menanggapi pembelajaran yang guru sampaikan. Sedangkan berkaitan dengan kecakapan, menanggapi dan memecahkan masalah siswa cenderung kurang aktif dalam merespon dan menyampaikan pendapatnya maupun inspirasinya.

Dari hasil data temuan secara keseluruhan yang diperoleh peneliti dapat disimpulkan bahwa siswa yang mempunyai latar belakang yang baik cenderung mampu mengikuti aturan, disiplin, kemauan belajar dan rasa ingin tau yang tinggi. Seperti halnya mengerjakan PR sesuai perintah guru, taat aturan, mudah diarahkan, bersikap mandiri dalam menghadapi pembelajaran, mampu memecahkan masalah melalui bertanya kepada guru dan memberikan jawaban atas pertanyaan guru. Namun hal tersebut hanya sebagian kecil saja.

Sedangkan siswa yang terbilang mempunyai kecerdasan kurang, identik biasa-biasa saja dalam menghadapi pembelajaran. Kemauan belajar dan rasa ingin tau yang kurang, tidak mengerjakan tugas/PR, sukar diarahkan, kurang mematuhi aturan, kurang bersikap mandiri dalam pembelajaran cenderung ikut-ikutan teman sebayanya dan tidak ada kemauan untuk bertanya dalam arti pasif dalam menentukan sikap pada saat pembelajaran.
Bahkan data temuan yang peneliti peroleh di lokasi penelitian tersebut masih banyak siswa yang tidak ada kemampuan membaca dan menulis sampai mencapai $32 \%$. Hal tersebut dapat dipastikan dapat dipengaruhi oleh kurangnya kemauan minat belajar siswa.

Sesuai yang dijelaskan oleh (Slameto : 2013) bahwa ada beberapa hal penting yang mempengaruhi minat belajar siswa diantaranya adalah sebagai berikut: 1) faktor intern yang meliputi; kesehatan, intellegensi, bakat, minat, perhatian, motif, kematangan dan kesiapan. 2) faktor ekstern yang meliputi; keluarga, lingkungan, metode mengajar, kurikulum, alat dan media.

\section{Faktor dan Upaya Meningkatkan Minat Belajar Siswa Dalam Meningkatkan Kecerdasan \\ Intelektual Siswa Di Wilayah Kabupaten Pandeglang.}

Dalam meningkatkan pendidikan yang berkualitas tentu ada upaya yang harus diterapkan oleh guru dalam meningkatkan kemauan siswa dalam belajar baik dari sikap, disiplin, perencanaan pembelajaran, berketerampilan, penggunaan metode, penyampaian dan cara menjelaskan. Sebagai guru tentu harus mampu membenahi bentuk profesionalitasnya 
tersebut.untuk merangsang kemauan siswa belajar.

Berdasarkan data hasil temuan di lapangan yang peneliti peroleh upaya yang dilakukan dalam meningkatkan kemauan siswa untuk meningkatkan kecerdasan intelektual siswa SD Negeri Wilayah Kabupaten Pandeglang adalah bahwa guru tetap berusaha dan berupaya menjadi yang terbaik bagi siswanya. Yang paling utama sebagai guru adalah menerapkan keprofesionalannya dengan mengembangkan beberapa kompetensi diri terlebih dahulu.

Kompetensi yang dimaksud sebagai upaya guru dalam meningkatkan kemauan belajar siswa adalah sesuai yang dijelaskan oleh (Prianti : 2019) dalam bukunya adalah sebagai berikut: Kompetensi pedagogik, Kompetensi Kepribadian, Kompetensi Sosial. 1) Kompetensi pedagogik yang meliputi; kemampuan dalam memahami peserta didik secara mendalam, kemampuan merancang pembelajaran, memahami landasan pendidikan, melaksanakan pembelajaran, melaksanakan evaluasi, menilai dan mengembangkan peserta didik. 2) Kompetensi Kepribadian yang meliputi; kesetabilan, dewasa, arif, berwibawa, adil, jujur dan berakhlak mulia. 3) Kompetensi Sosial; kemamapuan guru dalam berkomunikasi, bergaul, bekerjasama, dan saling memberikan pandangan kepada orang lain secara efektif dan efisien. Hal serupa yang dijelaskan oleh (Kunandar : 2011) menjelaskan bahwa sebagai guru harus professional yang dimaksudkan adalah bahwa guru harus memiliki kompetensi yang dipersyaratkan untuk melakukan tugas pendidikan dan pengajaran, kompetensi yang dimaksud meliputi pengetahuan, sikap, keterampilan, sosial dan akademis.

Selain itu, dari data hasil temuan yang diperoleh peneliti melalui wawancara dengan informan bahwa sebagai upaya dalam meningkatkan minat belajar siswa dalam meningkatkan kecerdasan intelektual siswa SD Negeri Wilayah Kabupaten Pandeglang. Dipandang dari sisi internal, dimana siswa mempunyai dorongan khusus untuk memiliki keinginan rasa ingin tau yang tinggi terhadap pembelajaran. Artinya tanpa ada perintah terlebih dahulu siswa berinisiatif melakukan belajar secara mandiri. berupaya dalam mengerjakan tugas, banyak membaca sebagai sumber dan pedoman. Kemudian faktor kesehatan, jika anak tidak ada kendala dalam kesehatan cenderung lebih fokus dalam menyimak dan memahami pembelajaran ketimbang dengan siswa yang mengalami gangguan kesehatan.

Sedangkan faktor eksternalnya adalah upaya keluarga dalam memotivasi anak dan memberikan dorongan untuk belajar 
dengan cara memberikan perhatian sepenuhnya kepada anak. Metode guru dalam mengajar, metode belajar keterampilan mengajar dipastikan dapat membangkitkan semangat belajar siswa. Dikarenakan semakin pembelajaran itu menyenangkan maka semakin siswa ingin memahaminya lebih dalam, karena ada ketertarikan tersendiri bagi siswa terhadap pembelajaran yang disampaikan.

Mengenai keterampilan guru dalam mengajar, semakin guru terampil dalam mengajar maka semakin menyenangkan pembelajaran itu bagi siswanya. Perhatian guru sepenuhnya, kasih sayang yang diberikan secara utuh kepada siswa dapat membentuk psikologi yang baik sehingga dapat menciptakan kemauan siswa dalam belajar.

Secara inti dapat disimpulkan sebagai upaya bahwa dengan terpenuhinya kriteria yang sesuai dalam pembelajaran dan kemampuan guru dalam menerapkannya, maka kemauan dan minat belajar siswa dalam meningkatkan kecerdasan intelektual siswa SD Negeri Wilayah Kabupaten Pandeglang akan terlaksana dengan baik.

\section{SIMPULAN}

Kecerdasan intelektual siswa dapat diciptakan oleh faktor internal siswa itu sendiri. Yang mana faktor internal itu yang paling mendominasi adalah faktor minat atau kemauan bakat (faktor bawaan) dan kesehatan. Sedangkan faktor eksternalnya adalah bersumber dari dorongan keluarga, lingkungan, dan bentuk profesionalitas guru. Secara inti dapat disimpulkan bahwa kemauan atau minat belajar siswa SD Negeri Wilayah Kabupaten Pandeglang yang saat ini belum dapat dikategorikan baik. Sebagai upaya yang dilakukan adalah bahwa guru tetap berusaha dan berupaya menjadi yang terbaik bagi siswanya, dengan mengembangkan beberapa kompetensi diri terlebih dahulu yaitu kompetensi pedagogik, kompetensi kepribadian, kompetensi Sosial. Dengan melalui penerapan kompetensi guru dapat dipastikan akan mendorong dan merangsang kemauan siswa untuk belajar.

\section{DAFTAR PUSTAKA}

Arikunto, Suharsimi. 2013. Prosedur penelitian. Jakarta. Rineka Cipta.

Baharuddin : 2010. Pendidikan \& Psikologi Perkembangan. Cetakan Ke-2. Jogjakarta: Ar-Ruzz Media.

Kunandar. 2011. Guru Professional (Implementasi Kurikulum KTSP dan Sukses dalam Sertifikasi Guru. Jakarta: PT. Raja Grafindo Persada.

Prianti. E. Nita. 2019. etika profesi guru dan profesionalisme guru dalam pembelajaran. Jakarta. PT. Grafindo Persada. 
Slameto : 2013. Belajar dan Faktorfaktor yang mempengaruhinya. Jakarta: Rineka Cipta.

Sugiyono. 2016. Metode Penelitian Kuantitatif, Kualitatif, dan $R \& D$. Cetakan Ke-23. Bandung: Alfabeta cv

Undang-Undang No.20 Tahun 2003.

Tentang Sistem Pendidikan

Nasional. Jakarta: Depdiknas. 